\title{
WINTER DISTRIBUTION AND GROUP COMPOSITION OF humpback whales (Megaptera novaeangliae) off northern Peru
}

\author{
Aldo S. Pacheco $2,3, *$, Sebastian Silva ${ }^{3}$ and Belén Alcorta ${ }^{3}$
}

\begin{abstract}
From late July to the end of September 2009, the temporal and spatial distribution and group composition of humpback whales (Megaptera novaeangliae) were studied in order to provide new information about the species in northern Peru, the southern limit of the breeding area for the Southeast Pacific population. Daily surveys were made from a whale-watching boat from Los Organos $\left(04^{\circ} 10^{\prime} 38.78^{\prime \prime} \mathrm{S}, 8^{\circ} 8^{\prime} 04.40^{\prime \prime} \mathrm{W}\right)$ and covering an area of approximately $74 \mathrm{~km}^{2}$. Data about geographic position and group composition are presented. A total of 43 trips yielded a total of 124 sightings. Whales were observed throughout the study period with a peak in abundance in late August. Humpbacks were distributed mainly in shallow waters between 20 and $50 \mathrm{~m}$ depth. Pairs and trios were the most common group type, whereas adults and mother/calf pairs were the principal sex/ age classes. Our data confirms breeding and nursing activities in the southern limit of the wintering area for the Southeast Pacific stock. Frequent use of the shallow waters of the northern Peruvian coast by fishing operations may cause negative impacts on this sensitive phase in the humpback's life cycle. Thus, strengthening the current protection measures is encouraged.
\end{abstract}

Resumen: Desde finales de julio a finales de septiembre de 2009, la distribución espacio temporal y composición del grupo de la ballena jorobada (Megaptera novaeangliae) fue estudiada para obtener información actualizada sobre la especie en la costa norte de Perú, zona que representa el límite sur del área de reproducción en el Pacifico Sureste. Se realizaron muestreos diarios desde una embarcación de turismo de observación de ballenas en Los Órganos (04 $\left.10^{\prime} 38.78^{\prime \prime S}, 81^{\circ} 8^{\prime} 04.40^{\prime \prime} \mathrm{W}\right)$ cubriendo un área de aproximadamente de $74 \mathrm{~km}^{2}$. Se colectaron y analizaron datos sobre la posición geográfica y composición del grupo. Se realizaron un total de 43 viajes en los que se avistó un total de 124 individuos. Las ballenas fueron observadas a lo largo de todo el periodo del estudio, con un máximo a finales de agosto. Las ballenas se distribuyeron en aguas someras de entre 20 y $50 \mathrm{~m}$ de profundidad. La mayoría de los grupos estuvieron formados por pares y tríos mientras que los adultos y las madres con cría fueron la clase grupal más importante, evidenciando que la actividad reproductora ocurre en el área. De esa forma se confirma el límite sur de la zona de crianza del stock del Pacifico Sureste. Las aguas costeras de la costa norte de Perú son frecuentemente usadas para la pesquería, las cuales pueden causar impactos negativos en las jorobadas. Dado que la migración a las áreas invernales es un estadio muy importante dentro del ciclo de vida de esta especie, se recomienda fortalecer las medidas de protección y conservación existentes.

KEYwORDs: humpback whale, Megaptera novaeangliae, migration, reproduction, Southeast Pacific, whale-watching

\section{Introduction}

Humpback whales (Megaptera novaeangliae) undertake the longest migration of all marine mammals, from their feeding grounds in polar waters to tropical and subtropical areas for breeding (e.g. Stone et al., 1990; Stevick et al., 2004; Acevedo et al., 2007; Rasmussen et al., 2007). Due to their proximity to the coast during migration, hundreds of humpback whales were hunted by the whaling fleets that operated in the Southeast Pacific between 1951 and 1987 (Ramírez and Urquizo, 1985; Ramírez, 1988a). Although the population was reduced, whaling for this species was not as intense as that for blue (Balaenoptera musculus) and Bryde's (B. edeni) whales (Ramírez and Urquizo, 1985; Ramírez, 1988a; b). Since the end of whaling activities in Peruvian waters in 1987, the Southeast Pacific stock has been increasing at an annual rate of about 5\% (Félix and Haase, 2001a; Félix, 2005). International research efforts are being conducted in order to obtain comprehensive information about population status and general ecology of the Southeast Pacific humpback whale, but also to mitigate a number of negative anthropogenic impacts (e.g. Félix et al., 1997; Félix and Hasse, 2005; Flórez-González et al., 2007; Van Waerebeek et al., 2007).

Critical phases during the life cycle of this species are migration and reproduction in tropical waters. Successful mating, calving, maternal care and calf learning are important processes occurring in such areas (e.g. Weinrich, 1998; Félix and Haase, 2001b; Cartwright and Sullivan, 2009), where surface activity is particularly intense (e.g. Félix, 2004). Recruitment and genetic variability of the population also depends on the time spent in a genetically mixed group during the reproductive season (Baker et al., 1990; 1993). Hence, it is important to generate knowledge about the extent of breeding areas and whether there are just a few specific reproductive spots or whether reproduction occurs over a larger spatial scale (i.e. Flórez-González et al., 1998; Félix et al., 2009). For the Southeast Pacific stock there is still a lack of knowledge about the migratory route from the feeding grounds in Antarctic waters to the reproductive area off Ecuador and Colombia (FlórezGonzález et al., 2007; Capella et al., 2008) thus, it is necessary to generate information (i.e. sightings) covering as much of the distributional area as possible for a better understanding of the dynamics of this population.

\footnotetext{
${ }^{1}$ Received on 12 December 2009. Accepted on 2 June 2010. Managed by Alexandre Zerbini.

2 Facultad de Recursos del Mar, Universidad de Antofagasta, Av. Angamos 601, P.O. Box 170, Antofagasta, Chile.

${ }^{3}$ Pacifico Adventures-Manejo Integral del Ambiente Marino S.A.C., Av. Rivera del Mar s/n, Los Organos, Piura, Perú.

* Corresponding author, e-mail: babuchapv@yahoo.com, Phone: 56-55-637404, Fax: 56-55-637804.
} 
There is some uncertainty about the distribution of baleen whales along the Peruvian coast, as available data are few and rather scattered (e.g. Van Waerebeek et al., 1996). Surveys are conducted opportunistically onboard research vessels for different purposes (e.g. the evaluation of pelagic or demersal fish stocks; Sánchez and Arias-Schreiber, 1998) or from land-based stations with limited temporal and spatial scales (e.g. Van Waerebeek et al., 1998; Anonymous, 2004; Santillán et al., 2004). To reduce potential bias, whale-watching trips seem to be a reasonable proxy for directed surveys.

For breeding stock G (IWC, 2006), northern Peru has been suggested to be a transitional area from oceanic to coastal waters during the reproductive migration to the coasts of Ecuador, Colombia and Panama (Félix and Haase, 2005; Flórez-González et al., 2007). However, data from whaling activities during 1961-1985 indicated that this coastal area could be considered as the southern limit of the breeding area for this stock (Ramírez, 1988a; Van Waerebeek et al., 1996; Félix and Haase, 2005) Recently, courtship behaviour has been observed in the waters surrounding Lobos de Tierra Island $\left(06^{\circ} 25.96^{\prime} \mathrm{S}\right.$, $80^{\circ} 52.27^{\prime} \mathrm{W}$ ) from land-based surveys ${ }^{4,5}$. Yet, there is very little information about breeding activities and patterns of habitat use in this area, therefore more information is necessary to fully understand population dynamics during the winter season in this area.

The aim of this paper is to provide new information about humpback whale breeding activities (i.e. presence of newborn whales), distributional patterns related to group composition and sex/age class in a coastal area of northern Peru. To achieve this, we analyzed data involving spatial and temporal distribution and social organization taken from a whale-watching boat, for the first time in the northern coast of Peru.

\section{Material and Methods}

Between 27 July and 28 September 2009, 43 trips were made aboard a whale-watching boat to study distributional aspects of the humpback whale during the wintering season (June-October) along the coastal area between Los Organos $\left(4^{\circ} 10^{\prime} 38.23^{\prime \prime} S\right.$, $\left.81^{\circ} 8.27^{\prime} 4.83^{\prime \prime} \mathrm{W}\right)$ and Cabo Blanco $\left(4^{\circ} 15^{\prime} 1.36^{\prime \prime S}\right.$, $\left.81^{\circ} 13^{\prime} 50.17^{\prime \prime} \mathrm{W}\right)$ off northern Peru (Figure 1$)$. The boat was $6.7 \mathrm{~m}$ long and $2.4 \mathrm{~m}$ wide with twin outboard Yamaha engines (85HP each). Trips started at 07:30h taking one of two routes (Figure 1); the first one going parallel to the coast from Los Organos to Cabo Blanco, while the second one consisted of a triangular transect going transversal to shore from Los Organos to La
Perelera bank (14km offshore), returning to El Nuro and finally Los Organos. Navigation usually was completed by 11:00h. Overall, trips covered a triangular area of ca. $74 \mathrm{~km}^{2}$. Once whales were located, they were approached keeping a distance of approximately 30$100 \mathrm{~m}$, in an attempt to minimize avoidance reaction while moving parallel the group in the same direction and with the same speed. If a whale surfaced closer to the boat, the engine was kept in neutral gear until the animal moved away from the boat. Observation time ranged from 10 to 40 minutes. During the observation period, information about the number of animals, relative age/ sex class composition and geographic position was taken. A group was defined as the total number of animals within $100 \mathrm{~m}$ radius, moving in the same direction and usually exhibiting similar behaviour (Félix and Haase, 2001b; Félix, 2004). Occasionally, groups of whales were sighted at close range, but they were not included as part of the group unless they showed obvious interaction with the first sighted group (Félix and Haase, 2001b). In addition, the most likely direction of displacement (distinguishing northeastward and southwestward direction) for each sighted whale was noted (i.e. referred to as the breathing and diving pattern while heading in a particular direction).

\section{Group composition}

Relative age/sex class and the composition of the whale groups were determined by naked eye. Whales were classified as adults (large size $>10 \mathrm{~m}$ ), subadults (medium size, 6-10m) or calves (small size $<6 \mathrm{~m}$ and always accompanied by a larger whale, presumably the mother). Groups were classified in one of the following categories: all adults (A), all sub adults (S), adults with sub adults (AS), mother with calf (MC), mother with calf and escort (ME) and mother with calf and more than one escort (MCE) (Félix and Hasse, 2001b; 2005). We note that it was not possible to reliably determine the physical maturity and sex based on size in all cases, even while on average adult females are larger than males.

\section{Results}

Humpback whales were sighted in 37 (86\%) of 43 trips in waters ranging from less than $20 \mathrm{~m}$ to $200 \mathrm{~m}$ depth. A total of 124 whales were registered in $150.5 \mathrm{~h}$ spent at sea. Animals were sighted throughout the study period at an average rate of $3.35(\mathrm{SD}=1.91)$ whales per trip, with two whales as the mode $(32.4 \%)$ and three $(27.02 \%)$ sighted whales as second most frequent value.

\footnotetext{
${ }^{4}$ García-Godos, I. and Van Oordt, F. (2007) Los mamíferos marinos de la Isla Lobos de Tierra, Perú. Page 152-153 in Extended Abstracts, Primer Congreso de Ciencias del Mar del Perú, 27-30 November 2007, Lambayeque, Perú.

${ }^{5}$ García-Godos, I., Van Oordt, F., Cardich, C. and León, S. (2008) La ballena jorobada (Megaptera novaeangliae) en isla Lobos de Tierra, un área potencial de reproducción al norte de Perú. Page 144 in Extended Abstracts, 13a Reunión de Trabajo de Especialistas en Mamíferos Acuáticos de América del Sur, 13-17 October 2008, Montevideo, Uruguay.
} 


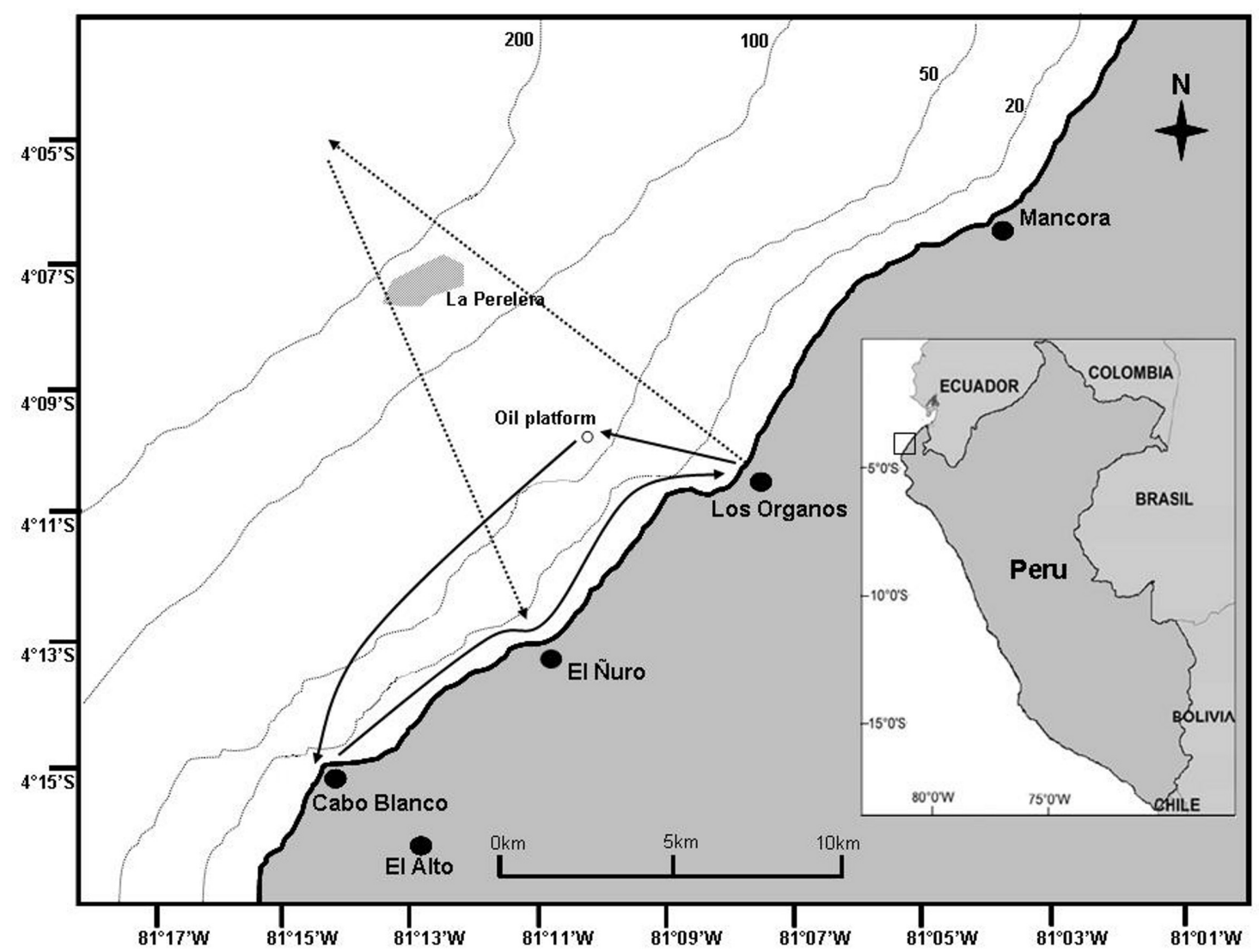

Figure 1. Study area, from Cabo Blanco to Organos, off Piura, northern Peru, and the routes used during surveys. The first route (solid arrows) consisted of sailing to the oil platform as navigation reference point, then heading south to Cabo Blanco before returning to Los Organos. The second route (dotted arrows) headed to La Perelera bank area and further offshore to the north-westernmost point located at $14 \mathrm{~km}$, and then returning inbound to El Nuro and finally back to Los Organos.

\section{Group size and composition}

A total of 60 groups were recorded. Group size ranged from one to eight individuals (mean=3.35, $\mathrm{SD}=1.91$ ). Groups of two individuals were the most commonly observed $(\mathrm{n}=31,51.66 \%)$, followed by single whales $(\mathrm{n}=17$, $28.33 \%)$, trios $(n=9,15 \%)$ and larger groups $(n=3,5 \%)$. Whales were mainly concentrated in shallow waters between 20 and $60 \mathrm{~m}$ depth. Groups larger than three $(n=2,5.4 \%$ with a maximum of eight whales) were only observed offshore, occurring two times on 24 and 28 August and passing La Perelera bank area, around the $200 \mathrm{~m}$ isobath and beyond.

Age/sex class composition of groups is shown in Figure 2. Thirty eight $(63.33 \%)$ groups were adults, while only five $(8.33 \%)$ were composed by sub-adults. Adults with sub-adults were observed three times (5\%) and mother/ calf pairs on eight occasions (13.3\%). Overall, mother/calf pairs with one and more than one escort accounted for the $23.29 \%(n=14)$. All adult groups and adults with sub-adults were widely distributed in the area, including waters of $200 \mathrm{~m}$ depth, while sub-adults and mother/calf pairs where exclusively encountered in shallow waters, in an average depth of $35 \mathrm{~m}$, and close to the shore (Figure 3). Without a reference measure, it was difficult to consistently distinguish groups in the field composed exclusively of sub-adults. Therefore, we urge caution when interpreting the data concerning to this type of group.

A monthly examination of the number of whales heading a particular direction of displacement showed similar proportions between northeast and southwest respectively: July $(n=3,60 \% ; n=2,40 \%)$, August $(n=13$, $44.8 \% ; n=16,55.2 \%)$ and September $(n=8,47.05 \% ; n=9$, $52.9 \%$ ). A one-way ANOVA comparing the total number of individuals moving southwestward $(n=27,49.09 \%)$ with the number of whales showing displacement northeastward $(n=24,43.63 \%)$ showed not significant differences $\left(\mathrm{F}_{(1,5)}=0.04, \mathrm{P}>0.05\right)$. Displacement with undetermined direction was observed four times accounting for the $7.27 \%$ of the observations of activity.

\section{Discussion}

This study documents for the first time the distribution of humpback whales in northern Peru using a whalewatching platform. Our results add support to the hypothesis of a continuous coastal distribution along the coasts of Costa Rica, Panama, Colombia, Ecuador and northern Peru for the reproductive activities of breeding stock G (Félix et al., 2009). The eight records of newborn calves in shallow waters in the study area agree with 


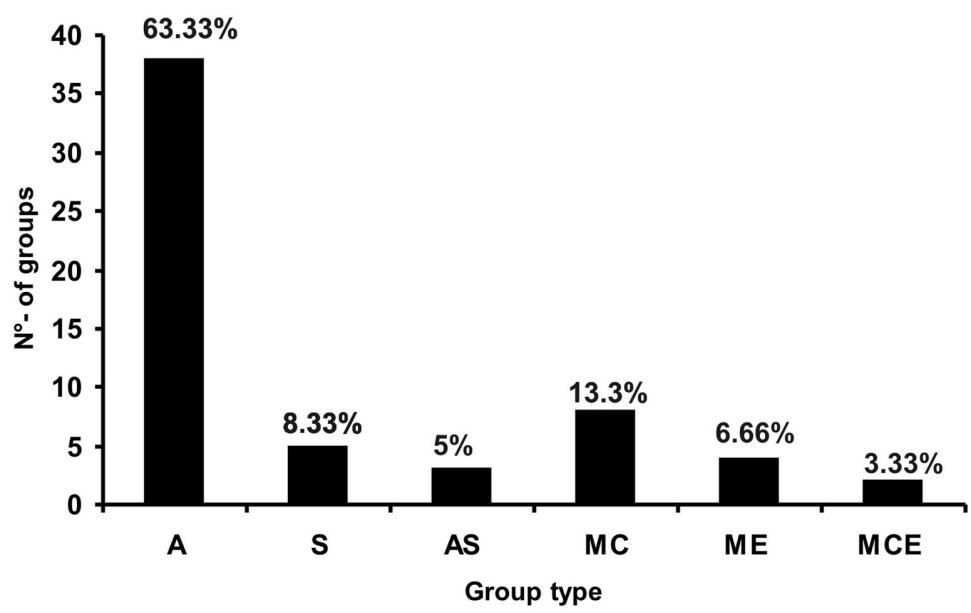

Figure 2. Group composition recorded during the study ( $\mathrm{n}=60)$. All adults (A), all sub adults (S), adults with sub adults (AS), mother with calf (MC), mother with calf and escort (ME) and mother with calf and more than one escort (MCE).

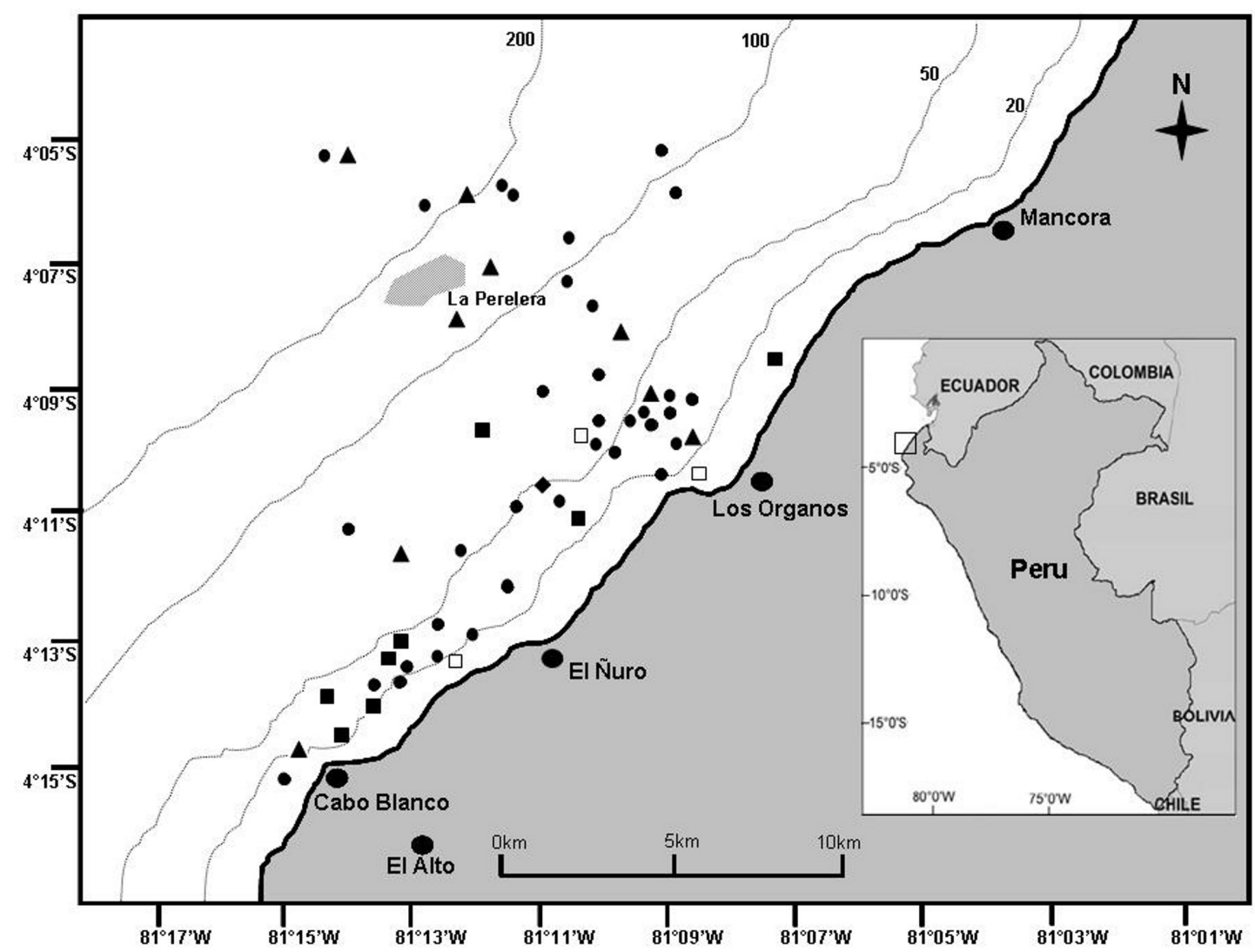

Figure 3. Relative age- and sex-class distribution of humpback whales in the study area. Symbols refer to GPS-positioned sightings during the studied period. Adults $(\bullet)$, Sub-adults $(\square)$, Adults and sub-adults $(\boldsymbol{\Delta})$, Mother and calf $(\boldsymbol{\bullet})$, undetermined $(\bullet)$.

previous studies in northern Peru (Ramírez 1988a), suggesting breeding activities during the transition from open oceanic waters to shallow waters of northern Peru. In this area humpback whales can be observed from the end of June until the end of December (Ramírez 1988a), similar to the wintering months reported for the coast of Ecuador and Colombia (Félix and Hasse, 2001b; Flórez-
González et al., 2007).

Our spatial distribution data was in agreement with the previous information regarding humpback whale preference for shallow waters less than $200 \mathrm{~m}$ depth in the wintering areas worldwide (Craig and Herman, 2000; Ersts and Rosenbaum, 2003; Zerbini et al., 2004; Johnston et al., 2007). The largest concentration of whales was 
observed in waters between $20 \mathrm{~m}$ and $50 \mathrm{~m}$, which is similar to the pattern reported off Ecuador (Félix and Hasse, 2001b; Félix and Haase, 2005). Although whales were observed in the entire depth range covered by the trips, age/sex class segregation in particular areas also occurred, with mother and calf pairs usually being distributed in very shallow and protected areas (see Félix and Haase, 2005). Based on whaling data for the northern coast of Peru (4-6 $6^{\circ}$ ), Félix and Haase (2005) suggested that humpback whales would be more widely distributed here, as this is a transitional area. Our results suggest concentration in shallow waters, resembling more the typical distribution pattern in wintering areas (e.g. Ersts and Rosenbaun, 2003; Zerbini et al., 2004; Johnston et al., 2007). However, additional information from offshore areas is needed to fully confirm this distributional pattern. Warm temperatures in the breeding area have been suggested as a critical factor driving the wintering migration of humpback whales (Corkeron and Connor, 1999; Félix and Hasse, 2001b; Rasmussen et al., 2009). Although, persistent upwelling cooling the water surface is a main characteristic in Peruvian coastal waters, the northern region (north of $8^{\circ} \mathrm{S}$; Swartzman et al., 2008) is frequently dominated by warmer water masses coming from the north (Zuta and Guillen, 1970; Swartzman et al., 2008). During autumn and winter, surface tropical waters are frequently found in this humpback whale wintering area (Rasmussen et al., 2009). Hence, the northern coast of Peru can be considered a habitat with water temperature appropriate for reproduction, calving, as well as a migratory destination of humpback whales. Félix and Haase (2005) surmised, based on their analysis of whaling data off the northern coast of Peru (4-6 $\left.6^{\circ}\right)$ that the area of convergence between the cold upwelling Humboldt Current and the warm equatorial waters to the north may serve as a clue that triggers the displacement of humpbacks from oceanic deep-water to a coastal breeding environment. Assuming that this transition occurs, our data would suggest that reproduction starts as soon as the animals approach the coastal area and not at further northerly destinations where most of breeding activities have been reported (Flórez-González et al., 2007). Off Hawaiian waters there is evidence suggesting that humpbacks can copulate during migration and sexual hormones levels are high before the arrival to the breeding area (e.g. Craig and Herman, 1997; 2000).

Whales swam in either northeast or southwest directions almost in equal proportions throughout the study period, suggesting constant movement within the area. During the breeding season, humpback whales are actively moving, males searching for receptive females while mother and calf pairs moving through shallow and protected areas. Nonetheless, they tend to concentrate in some locations for relative short periods of time (Scheidat et al., 2000; Félix and Haase, 2001b).

The coastal waters of northern Peru are frequently used for artisanal and industrial fisheries, which may negatively impact the whales during the winter season. Considering that breeding is a critical and sensitive phase in the life cycle of this species, we encourage further strengthening of the existing conservation and management recommendations that have been made for the Southeast Pacific population (Flórez-González et al., 2007).

\section{Acknowledgements}

We thank the Pacifico Adventures crew, Cesar Correa, Segundo Pizarro and Aldo Muñoz for their support and expertise during field trips. Ignacio Garcia-Godos, Koen Van Waerebeek and two reviewers provided useful comments that helped us to improve an early draft of this manuscript. We also thank Daniel Palacios for correcting and editing the final version of this article.

\section{References}

Acevedo, J., Rasmussen, K., Félix, F., Castro, C., Llano, M., Secchi, E., Saborío, M.T., Aguayo-Lobo, A., HaAse, B., Scheidat, M., Dalla-Rosa, L., Olavarría, C., Forestell, P., Acuña, P., Kaufman, G., Pastene, L.A. (2007) Migratory destinations of humpback whales from the Magellan strait feeding ground, Southeast Pacific. Marine Mammal Science 23(2): 453-463.

AnONymous (2004) Peru. Progress Report on cetacean research, March 1995 to March 2004, with statistical data for 1997-2002. National report presented to the 56th IWC Scientific Committee meeting, July 2004, Sorrento, Italy. SC/56/ProgRep. 5pp. [Available from the Office of the International Whaling Commission, The Red House, 135 Station Road, Impington, Cambridge, Cambridgeshire CB4 9NP, UK, <http://iwcoffice.org/>].

Baker, C.S., Palumbi, S.R., Lambertsen, R.H., Weinrich, M.T., Calambokidis, J. AND O’Brien, S.J. (1990) Influence of seasonal migration on geographic distribution of mitochondrial DNA haplotypes in humpback whales. Nature 344: 238-240.

Baker, C.S., Perry, A., Bannister, J.L., Weinrich, M.T., Abernethy, R.B., Calambokidis, J., Lien, J., LAmbertsen, R.H., Urban RamíreZ, J., Vasquez, O., Clapham, P.J., Alling, A., O’Brien, S.J. And PAlumbi, S.R. (1993) Abundant mitochondrial DNA variation and world-wide population structure in humpback whales. Proceedings of the National Academy of Science USA 90: 8239-8243.

Capella, J., Gibbons, J., Flórez-González, L., Llano, M., VAlladARES, C., SABAJ, V. AND VILINA, Y. (2008) Migratory roundtrip of individually identified humpback whales at the Strait of Magellan: clues on transit times and phylopatry to destinations. Revista Chilena de Historia Natural 81: 547-560.

CARTwRIGHT, R. AND SulLIVAN, M. (2009) Behavioural ontogeny in humpback whale (Megaptera novaeangliae) calves during their residence in Hawaiian waters. Marine Mammal Science 25(3): 659-680.

Corkeron, P.J. And Connor, R.C. (1999) Why do baleen whales migrate? Marine Mammal Science 15: 1228-1245.

CRAIG, A.S. AND HERMAN, L.M. (1997) Sex differences in site fidelity and migration of humpback whales (Megaptera novaeangliae) to Hawaiian Islands. Canadian Journal of Zoology 75: 1923-1933.

CRAIG, A.S. AND Herman, L.M. (2000) Habitat preferences of female humpback whales Megaptera novaeangliae in the Hawaiian Islands are associated with reproductive status. Marine Ecology Progress Series 193: 209-216. 
ERsts, P.J. And Rosenbaum, H.C. (2003) Habitat preference reflects social organization of humpback whales (Megaptera novaeangliae) on a wintering ground. Journal of Zoology 260: 337-45.

FÉLIX, F. (2004) Assessment of the level of surface activity in humpback whales during the breeding season. The Latin American Journal of Aquatic Mammals 3(1): 25-36.

FÉLIX, F. (2005) Guía de campo para la observación de ballenas jorobadas en la costa de Ecuador. Fundación Ecuatoriana para el estudio de Mamíferos Marinos (FEMM)/Casa de la cultura Ecuatoriana Núcleo del Guayas. Segunda Edición. Guayaquil, Ecuador. 32p.

FÉlix, F. AND HaAse, B. (2001a) Towards an estimate of the southeastern Pacific humpback whale stock. Journal of Cetacean Research and Management 3(1): 55-58.

FÉlIX, F. AND HaAse, B. (2001b) The humpback whale off the coast of Ecuador, population parameters and behaviour. Revista de Biologia Marina y Oceanografia. 36: 61-74.

FÉLIX, F. AND HAASE, B. (2005) Distribution of humpback whales along the coast of Ecuador and management implications. Journal of Cetacean Research and Management 7(1): 21-31.

Félix, F., Haase, B., Davis, J.W., Chiluiza, D. and Amador, P. (1997) A note on recent strandings and bycatches of sperm whales (Physeter macrocephalus) and humpback whales (Megaptera novaeangliae) in Ecuador. Reports of the International Whaling Commission 47: 917-919.

Félix, F., Rasmussen, K., Garita, F., HaAse, B. AND Simonis, A. (2009) Movements of humpbacks whales between Ecuador and Central America, wintering area of the breeding stock G. Paper SC/61/ SH18 presented to the 61st Scientific Committee of the International Whaling Commission. Madeira, Portugal, June 2009. [Available from the Office of the International Whaling Commission, The Red House, 135 Station Road, Impington, Cambridge, Cambridgeshire CB4 9NP, UK, <http://iwcoffice.org/>].

Flórez-González, L., Capella, J., Haase, B., Bravo, G., Félix, F. AND Gerrodette, T. (1998) Changes in winter destinations and the northernmost record of southeastern Pacific humpback whales. Marine Mammal Science 14(1): 189-196.

Flórez-González, L., Ávila, I.C., Capella, J., Falk, P., Félix, F., Gibbons, J., Guzmán, H.M., HaAse, B., Herrera, J.C., Peña, V., Santillán, L., Tobón I. C. and Van Waerebeek, K. (2007) Estrategia para la conservación de la ballena jorobada del Pacífico Sudeste. Lineamientos de un plan de acción regional e iniciativas nacionales. Fundación Yubarta. Cali. Colombia. 106 p.

INTERNATIONAL WhaLING COMMISSION (2006) Report of the Scientific Committee. Annex H, report of the Sub-Committee on other Southern Hemisphere whale stocks. Saint Kitts, June 2006. 24pp. [Available from the Office of the International Whaling Commission, The Red House, 135 Station Road, Impington, Cambridge, Cambridgeshire CB4 9NP, UK, <http://iwcoffice.org/>1

Johnston, D.W., Chapla, M.E., Willians, L.E. and Mattila, D.K. (2007) Identification of humpback whales (Megaptera novaeangliae) wintering habitat in the Northwestern Hawaiian Islands using spatial habitat modeling. Endangered Species Research 3: 249-257.

RAMírez, P. (1988a) La ballena jorobada Megaptera novaeangliae en la costa norte de Perú: periodos 1961-1966 y 1975-1985. Boletín de Lima 56: 91-96.

RAMÍREZ, P. (1988b) Capturas de ballena sei (Balaenoptera borealis) frente a Paita, Perú. Pages 341-343 in SALZwEDEL, H. AND LANDA, A. (Eds) Recursos y dinámica del ecosistema de afloramiento peruano. Boletín Volumen Extraordinario, Instituto del Mar del Perú, Callao, Perú.
RAMÍREZ,P. AND URQUIZO, W. (1985) Los cetáceos mayores y el fenómeno “El Niño" 1982-1983. Pages 201-206 in ARNTZ, W., LANDA, A. AND TARAZONA, J. (Eds) "El Niño" su impacto en la fauna marina. Boletín Volumen Extraordinario, Instituto del Mar del Perú, Callao, Perú.

Rasmussen, K., Palacios, D.M., Calambokidis, J., Saborío, M.T., Dalla Rosa, L., Secchi, E.R., Steiger, G.H., Allen, J.M. AND Stone, G.S. (2007) Southern Hemisphere humpback whales wintering off Central America: insights from water temperature into the longest mammalian migration. Biology Letters 3: 302-305.

SÁNCHEZ, R. AND ARIAS-Schreiber, M. (1998) Cetáceos observados frente a la costa peruana y su relación con la distribución y abundancia de los recursos pelágicos. Crucero BIC Humboldt 980809, de Paita a Callao. Informe Instituto del Mar del Perú 141:55-66.

Santillán, L., Roca, M., Apaza, M., de Oliveira, R. and Ontón, K. (2004) New record of mother-calf pair of southern right whale Eubalaena australis off the Peruvian coast. The Latin American Journal of Aquatic Mammals. 3: 83-84.

Scheidat, M., Castro, C., Denkinger, J., González, J. And Adelung, D. (2000) A breeding area for humpback whales (Megaptera novaeangliae) off Ecuador. Journal of Cetacean Research and Management 2(3): 165-171.

Stevick, P.T., Aguayo, A., Allen, J., Avila, I.C., Capella, J., Castro, C., Chater, K., Engel, M., Félix, F., Flórez-González, L., Freitas, A., Hasse, B., Llano, M., Lodi, L., Munoz, E., Olavarría, C., SeCChI, E., SCheidat, M. AND Siciliano, S. (2004) A note on the migrations of individually identified humpback whales between the Antarctic Peninsula and South America. Journal of Cetacean Research and Management 6(2): 109-113.

Stone, G.S., FlóREZ, L. AND KATONA, S. (1990) Whale migration record. Nature 346: 705 .

Swartzman, G., Bertrand, A., Gutíerrez, M., Bertrand, S. and VASOUEZ, L. (2008) The relationship of anchovy and sardine to water masses in the Peruvian Humboldt Current System from 1983 to 2005. Progress in Oceanography 79: 228-237.

Van Waerebeek, K., Alfaro-Shigueto, J., Arias-Schreiber, M. (1996) Humpback whales off Peru: new records and a rationale for renewed research. International Whaling Commission Scientific Committee document SC/48/SH1, Aberdeen, UK, June 1996. [Available from the Office of the International Whaling Commission, The Red House, 135 Station Road, Impington, Cambridge, Cambridgeshire CB4 9NP, UK, <http://iwcoffice.org/>]

Van Waerebeek, K., Reyes, J.C. and Van BRessem, M.F. (1998) Sighting of a mother-calf pair of southern right whale Eubalaena australis in Peruvian waters. Estudios Oceanologicos 17: 105-107.

VAN WAEREBEeK, K., BAKER, A.N., FÉlix, F., GedAMKE, J., IñIgUeZ, M., Sanino, G.P., Secchi, E., Sutaria, D., Van Helden, A. and Wang, Y. (2007) Vessel collisions with small cetaceans worldwide and with large whales in the southern hemisphere, an initial assessment. The Latin American Journal of Aquatic Mammals. 6(1): 43-69.

WeINRICH, M. (1998) Early experience in habitat choice by humpback whales (Megaptera novaeangliae). Journal of Mammalogy. 79(1): 163-170.

Zerbini, A.N., ANDriolo, A., DA Rocha, J.M., Simoes-Lopes, P.C., Siciliano, S., Pizzorno, J.L., Waite, J.M., DeMaster, D.P. And VAnBlaricom, G. (2004) Winter distribution and abundance of humpback whales (Megaptera novaeangliae) off Northeastern Brazil. Journal of Cetacean Research and Management 6(1): 101-107.

Zuta, S. AND GuILLEN, O. (1970) Oceanografía de las aguas costeras del Perú. Boletín del Instituto del Mar del Perú. 2: 157-324. 